\title{
Analysis of physico-chemical parameters of soil and population density of Azospirillum isolates from paddy fields of Theni district, Tamilnadu
}

\section{S. Uma Devi*}

Department of Microbiology and Biochemistry, Nadar Saraswathi College of Arts and Science, Theni - 625531 (Tamil Nadu), India

K. Muthuchelian

Department of Bioenergy, School of Energy, Environment and Natural Resources, MaduraiKamaraj University, Madurai - 625021 (Tamil Nadu), India

*Corresponding author. E-mail: spu.uma@gmail.com

\begin{abstract}
The rhizosphere region of eight different paddy field areas of Theni district was studied for their physico-chemical analysis of soil and the population density of Azospirillum sp. The study results showed range of values of $\mathrm{pH}(7.4-7.9)$, bulk density $(1.13 \mathrm{~g} / \mathrm{cm} 3-1.60 \mathrm{~g} /$ $\mathrm{cm} 3)$, water holding capacity $(34.31 \%-18.25 \%)$, electrical conductivity $(1.31-1.11)$, organic carbon $(0.93 \%-0.71 \%)$. The macronutrient values namely total nitrogen $(1.72 \%$ - $0.78 \%)$, phosphorus content $(0.177 \%-0.122 \%)$ and potassium $(1.364 \%-1.273 \%)$ were observed. Also micronutrients of various paddy fields like $\mathrm{Zn}(0.9 \%-0.5 \%)$, Cu $(2.3 \%-$ $1.7 \%)$, Fe $(10.9 \%-8.2 \%)$, Mn (6.7\% - 5.2\%) were recorded, whereas the values of available macronutrients namely nitrogen $(295 \mathrm{~kg} / \mathrm{ha}-223 \mathrm{~kg} / \mathrm{ha})$, phosphorous $(89 \mathrm{Kg} / \mathrm{acre}$ $49 \mathrm{~kg} / \mathrm{acre})$, potassium $(790 \mathrm{~kg} / \mathrm{acre}-490 \mathrm{~kg} / \mathrm{acre})$ were noted. The Azospirillum population density was highest in Chinnamanur $\left(192 \times 10^{5} \mathrm{CFU} / \mathrm{g}\right)$ and lowest in Royyanpatti (91 $\times 10^{5} \mathrm{CFU} / \mathrm{g}$ ). Thus through this work we were able to isolate and identify novel high yielding Azosprillium sp from paddy fields of Theni district.
\end{abstract}

Keywords: Azospirillum, Paddy, Population density, Rhizosphere, Soil, Theni

\section{INTRODUCTION}

The microbial load in any soil depends mainly on the soil physical and chemical parameters, which in turn bring out the structural stability and fertility (Ketterings et al., 1997). Any agro ecosystems are influenced by the intensity and distribution of various living organisms (Paoletti, 1999; Narayan and Gupta, 2018). Each parameters of soil has direct influence on the microbial community thereby bringing about sustainability in agriculture (Ivask et al., 2008).

The PGPR strains namely Azospirillum., Azotobacter and Enterobacter promote the plant growth by colonizing the rhizosphere region of soil (Haiyambo and Chimwamurombe, 2018). Azospirillum, a versatile organism mostly associated with roots of cereals and grasses and especially rice, maize, wheat and vegetables. The interaction of plant- bacteria depends on various environmental factors and also chemotactic factors at the rhizosphere region of soil (Lopez-de-victoria, 1989). They promote plant growth by fixing nitrogen in available form to plants and also inducing resistance towards pathogens (Mohamed et al., 2018). Thus, it is important to isolate and identify

\section{Article Info}

DOI:10.31018/jans.v11i1.1972 Received: December 23, 2018 Revised: January 27, 2019

Accepted: February 5, 2019

\section{How to Cite}

Devi, S. U. and Muthuchelian, K. (2019). Analysis of physico-chemical parameters of soil and population density of Azospirillum isolates from paddy fields of Theni district, Tamilnadu. Journal of Applied and Natural Science, 11(1): $88-93$ the Azospirillum from crops.

The present study focusses on the various physico-chemical parameters of soil of eight sampling areas in Theni district namely Erasanackainur, Chinnamanur, Uthamapalayam, Kuchanoor, Royappanpatti, Veerapandi, Kottur and Upparpatti and on isolation of Azospirillumsp from these paddy fields at Theni district, Tamilnadu. Also the population density of Azospirillum sp at different paddy fields will be enumerated.

\section{MATERIALS AND METHODS}

Location of Theni district: Theni District lies at latitude $9030^{\prime}$ of $10030^{\prime}$ and longitude $77000^{\prime}$ of 78030 ' with cover area of 3242.30 sqkm, accounts for $2.2 \%$ total area in Tamilnadu. Theni district is bound by Madurai on east, Idukki on west, Dindigul on north and Virudhunagar on south sides. There are five Taluks namely Theni, Periyakulam, Andipatti, Uthamapalayam and Bodinayakanur. There are eight Community Development (CD) Blocks enclosing 80 revenue villages, 5 municipalities and 23 town panchayats. Agriculture is the main occupation in this district. The temperature ranges between 26.3 and $38.5^{\circ}$ $\mathrm{C}$ and climate is enjoyable in Theni district, with 
Devi, S. U. and Muthuchelian, K. / J. Appl. \& Nat. Sci. 11(1): 88 - 93 (2019)

medium rainfall of $829.8 \mathrm{~mm}$ depending mainly on North East monsoon rains. The total area of Theni district is $288923 \mathrm{Ha}$. The dominant soli types in Theni district are red loam, lateritic soil, black soil, sandy coastal alluvium and red sandy soil.

In terms of agricultural development, Theni district ranks 29 among all districts of Tamilnadu. Among the total cropped areas in Theni district, paddy and sugarcane occupies $13 \%$. Theni, Uthamapalayam, Cumbum, Chinnamanur blocks are toppers in paddy cultivation. The irrigated cropped area is largely used for paddy cultivation (95\%) in almost all blocks of Theni district.

Collection of samples: The selection of paddy fields of the district Theni was done based upon the physiological appearance of the paddy grown in the field. The soil samples were collected along with the live plant roots (Table 1).

Rhizosphere paddy soils were collected from the rhizosphere regions of the plant at the depth of 2$3 \mathrm{~cm}$ and non rhizosphere paddy soil sample was collected from 6 feet away from each plant. The plants were uprooted for root sample and the paddy soils attached to the roots were removed. All samples were taken in different polythene bags and brought to the laboratory. Samples from particular site were bundled together and considered as single sample. From this sample, soil was collected from the rhizosphere region at $4-5 \mathrm{~cm}$ depth, beneath the soil.

Analysis of physico - chemical parameters of the soil: The soil samples were suspended in distilled water $(1: 2 \mathrm{w} / \mathrm{v})$ and allowed to settle down. After which $\mathrm{pH}$, electrical conductivity $(\mu S)$ and cation exchange capacity (CEC) $\left(\mathrm{dsm}^{-1}\right)$ of the soil was determined using $\mathrm{pH}$ meter (Systronics, India) and procedure of Jackson (1973).

Nutrient analysis: The following standard procedures were used for determination of organic carbon (OC) (\%) content Walkley and Black (1934), available nitrogen (Subbiah and Asija, 1956) and available Phosphorus, potassium $(\mathrm{Kg} / \mathrm{ha})$ content using flame photometer (Stanford and English, 1949), calcium (Jackson, 1973), magnesium, sodium and available iron $(\mathrm{mg} / \mathrm{kg}$ ) (Muthuvel and Udayasoorian, 1999). Atomic Absorption Spectrophotometer (Perkin-Elmer Model 2280) was used for analysis of available micronutrients such as $\mathrm{Zn}, \mathrm{Cu}, \mathrm{Mn}$ (mg/kg) (Lindsay and Norvell, 1978).

Isolation of Azospirillum: The collected soil samples of weight 1 gram was taken and serially diluted using sterile distilled water up to $10^{8}$ dilutions and one $\mathrm{ml}$ of diluted sample from $10^{-6}$ to $10^{-}$ ${ }^{8}$ dilutions was taken and $0.1 \mathrm{ml}$ of aliquot was inoculated in test tube containing $\mathrm{Nfb}$ (Nitrogen free bromothymol) semisolid medium. The tubes were incubated at $32{ }^{\circ} \mathrm{C}$ for $48 \mathrm{hrs}$ and observed for pellicle formation. After this pellicles were transferred to fresh Nfb broth media and streaked on $\mathrm{Nfb}$ solid media, incubated at $32{ }^{\circ} \mathrm{C}$ for $24 \mathrm{hrs}$. Azospirillum colonies showing any difference in morphology and color (white, yellow, pink) were selected and streaked on minimal salt agar medium, incubated at $32{ }^{\circ} \mathrm{C}$ for $24 \mathrm{hrs}$ (Baldani and Dobereiner, 1980).

Microscopic observation: The $24 \mathrm{hrs}$ old culture of Azospirillum isolates was observed for cell morphology, gram's staining and motility. Then the slides were observed under light microscope. The results of gram reactions and cell morphology was noted. Motility of isolates was tested by keeping a drop of culture suspension on cavity slide and observed for characteristic spiralling motility under oil immersion objective of a microscope (100 X).

Enumeration of Azospirillum isolates: The isolates of Azospirillum cells in $\mathrm{Nfb}$ solid medium were counted by using Qubec colony counter and population density expressed in terms of colony forming unit (CFU)/g of soil with dilution factor.

Number of colonies (average of three replicates)

Number of viable cells/ml= Amount of inoculum plated dilution

....Eq. 1

Differentiation of Azospirllum from other root colonies: The Azospirillum $s p$ colonies showing morphological and staining characters were further subjected to streaked on to RC agar plates (PH 7.0) (Rodriguez, 1982).

\section{RESULTS AND DISCUSSION}

Rhizosphere, play crucial role in development and growth of plant, as a lot of nutrients are excreted from root hairs, this attracts wide array of organisms. The texture of soil is influenced by water availability and the soil type water holding ability

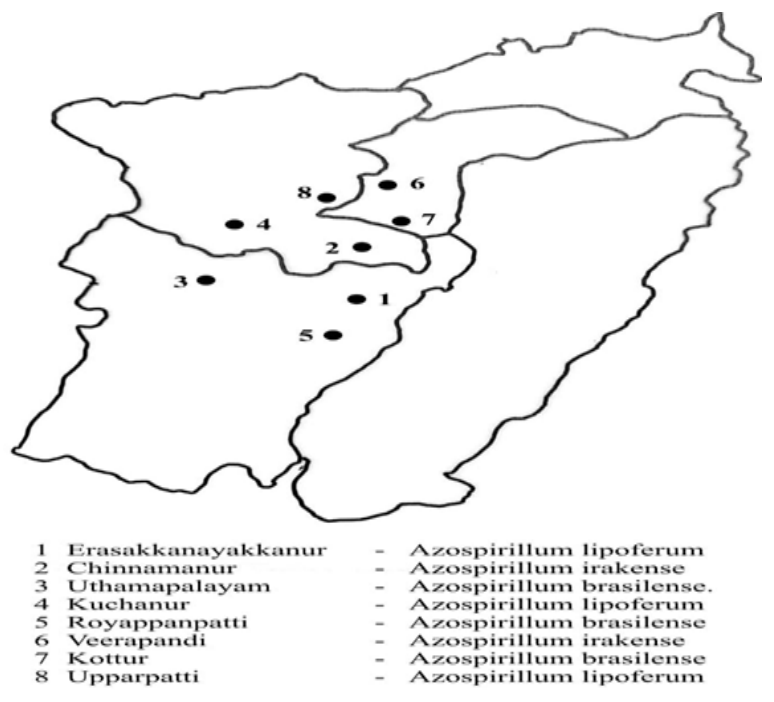

Fig. 1. Map showing the study areas and organisms isolated at study locations of Theni district, Tamil Nadu. 
Devi, S. U. and Muthuchelian, K. / J. Appl. \& Nat. Sci. 11(1): 88 - 93 (2019)

Table 1. Physiological appearance of soil samples of study areas.

\begin{tabular}{llll}
\hline Sample No. & Study area & Soil texture & Soil structure \\
\hline S1 & Erasakkanaickanur & Red soil & Granular \\
S2 & Chinnamanur & Lateritic soil & Crumb \\
S3 & Uthamapalayam & Sandy loam soil & Granular and blocky \\
S4 & Kuchanur & Black soil & Blocky \\
S5 & Royappanpatti & Sandy loam soil & Blocky and crumb \\
S6 & Veerapandi & Clay soil & Crumb \\
S7 & Kottur & Black soil & Granular and blocky \\
S8 & Upparpatti & Black soil & Blocky and crumb \\
\hline
\end{tabular}

Table 2. Physico - chemical properties of various paddy field soil samples at Theni District.

\begin{tabular}{|c|c|c|c|c|c|c|c|}
\hline S.N. & Sampling places & Texture & $\mathrm{pH}$ & $\begin{array}{l}\text { Bulk density } \\
\text { (g/cm } 3)\end{array}$ & $\begin{array}{l}\text { Water holding } \\
\text { capacity (\%) }\end{array}$ & $\begin{array}{l}\text { Electrical } \\
\text { conductivity } \\
\left(\text { dsm }^{-1}\right)\end{array}$ & $\begin{array}{l}\text { Organic } \\
\text { Carbon } \\
\%\end{array}$ \\
\hline 1. & Erasakkanaickanur & Red soil & 7.8 & 1.340 & 21.240 & 1.12 & 0.76 \\
\hline 2. & Chinnamanur & $\begin{array}{l}\text { Lateritic } \\
\text { soil }\end{array}$ & 7.7 & 1.460 & 32.170 & 1.23 & 0.93 \\
\hline 3. & Uthamapalayam & $\begin{array}{l}\text { Sandy } \\
\text { loam }\end{array}$ & 7.9 & 1.520 & 25.250 & 1.31 & 0.81 \\
\hline 4. & Kuchanoor & Black soil & 7.5 & 1.590 & 34.310 & 1.14 & 0.88 \\
\hline 5. & Royappanpatti & $\begin{array}{l}\text { Sandy } \\
\text { loam }\end{array}$ & 7.3 & 1.130 & 18.520 & 1.11 & 0.74 \\
\hline 6. & Veerapandi & Clay soil & 7.8 & 1.180 & 24.700 & 1.22 & 0.81 \\
\hline 7. & Kottur & Black soil & 7.9 & 1.610 & 29.310 & 1.18 & 0.78 \\
\hline 8. & Upparpatti & Black soil & 7.4 & 1.175 & 24.470 & 1.15 & 0.71 \\
\hline
\end{tabular}

Table 3. Micronutrients and macronutrients of various paddy field soil samples at Theni District.

\begin{tabular}{|c|c|c|c|c|c|c|c|c|c|c|c|}
\hline \multirow[t]{2}{*}{ S.N. } & \multirow[t]{2}{*}{ Sampling places } & \multicolumn{3}{|c|}{ Total Nutrients (\%) } & \multicolumn{4}{|c|}{$\begin{array}{l}\text { Available Micro Nutri- } \\
\text { ents }(\mathrm{mg} / \mathrm{kg})\end{array}$} & \multicolumn{3}{|c|}{$\begin{array}{l}\text { Available macronutri- } \\
\text { ents }(\mathrm{Kg} / \mathrm{ha})\end{array}$} \\
\hline & & $\mathbf{N}$ & $\mathbf{P}$ & $\mathbf{K}$ & $\mathbf{Z n}$ & $\mathrm{Cu}$ & $\mathrm{Fe}$ & Mn & $\mathbf{N}$ & $\mathbf{P}$ & $\mathbf{K}$ \\
\hline 1. & Erasakkanaickanur & 1.25 & 0.163 & 1.273 & 0.7 & 1.7 & 8.2 & 6.1 & 223 & 62 & 578 \\
\hline 2. & Chinnamanur & 1.72 & 0.176 & 1.281 & 0.6 & 1.9 & 10.9 & 5.9 & 295 & 84 & 790 \\
\hline 3. & Uthamapalayam & 1.68 & 0.156 & 1.296 & 0.8 & 2.2 & 10.7 & 5.5 & 263 & 89 & 693 \\
\hline 4. & Kuchanoor & 1.53 & 0.139 & 1.350 & 0.9 & 2.0 & 9.5 & 5.2 & 237 & 49 & 682 \\
\hline 5. & Royappanpatti & 0.78 & 0.130 & 1.329 & 0.6 & 1.8 & 9.5 & 6.4 & 245 & 51 & 710 \\
\hline 6. & Veerapandi & 0.92 & 0.141 & 1.330 & 0.5 & 1.8 & 10.1 & 6.7 & 251 & 63 & 340 \\
\hline 7. & Kottur & 1.37 & 0.167 & 1.364 & 0.8 & 2.3 & 9.1 & 6.0 & 244 & 60 & 674 \\
\hline 8. & Upparpatti & 1.19 & 0.122 & 1.328 & 0.8 & 2.2 & 9.4 & 5.8 & 230 & 75 & 490 \\
\hline
\end{tabular}

$\mathrm{N}=$ Nitrogen; $\mathrm{P}=$ Phosphorous; $\mathrm{Zn}=\mathrm{Zinc} ; \mathrm{Cu}=$ Copper; Fe=Iron; $\mathrm{Mn}=$ Manganese

Table 4. Colony characteristics of paddy field soil sample isolates and their population density of Theni district.

\begin{tabular}{|c|c|c|c|c|}
\hline S.N. & Sampling places & $\begin{array}{l}\text { Colony characteristics in BMS } \\
\text { medium }\end{array}$ & $\begin{array}{l}\text { Name of } \\
\text { Organism }\end{array}$ & $\begin{array}{l}\text { No. of population } \times 10^{5} \\
\text { dilution CFU/g of soil }\end{array}$ \\
\hline 1. & Erasakkanaickanur & $\begin{array}{l}\text { Off-white, small round irregular } \\
\text { margin, shiny colonies }\end{array}$ & $\begin{array}{l}\text { Azospirillum } \\
\text { lipoferum }\end{array}$ & 107 \\
\hline 2. & Chinnamanur & $\begin{array}{l}\text { Yellowish, medium, wringled, moist } \\
\text { colonies }\end{array}$ & $\begin{array}{l}\text { Azospirillum } \\
\text { irakense }\end{array}$ & 192 \\
\hline 3. & Uthamapalayam & $\begin{array}{l}\text { Grayish medium, round, convex, } \\
\text { slightly moist colonies }\end{array}$ & $\begin{array}{l}\text { Azospirillum } \\
\text { brasilense }\end{array}$ & 154 \\
\hline 4. & Kuchanoor & $\begin{array}{l}\text { Off-white, medium, circular, shiny, } \\
\text { flat with irregular margin colonies }\end{array}$ & $\begin{array}{l}\text { Azospiril- } \\
\text { lumlipoferum }\end{array}$ & 126 \\
\hline 5. & Royappanpatti & $\begin{array}{l}\text { Off-white, small round, irregular } \\
\text { margin, shiny colonies }\end{array}$ & $\begin{array}{l}\text { Azospirillum } \\
\text { brasilense }\end{array}$ & 91 \\
\hline 6. & Veerapandi & $\begin{array}{l}\text { Yellowish, medium, round convex, } \\
\text { shiny, dry colonies }\end{array}$ & $\begin{array}{l}\text { Azospirillum } \\
\text { irakense }\end{array}$ & 138 \\
\hline 7. & Kottur & $\begin{array}{l}\text { Yellowish, medium, round, moist, } \\
\text { shiny, convex colonies }\end{array}$ & $\begin{array}{l}\text { Azospirillum } \\
\text { brasilense }\end{array}$ & 175 \\
\hline 8. & Upparpatti & $\begin{array}{l}\text { Off-white, medium, circular, shiny } \\
\text { flat with irregular margin colonies }\end{array}$ & $\begin{array}{l}\text { Azospirillum } \\
\text { lipoferum }\end{array}$ & 167 \\
\hline
\end{tabular}




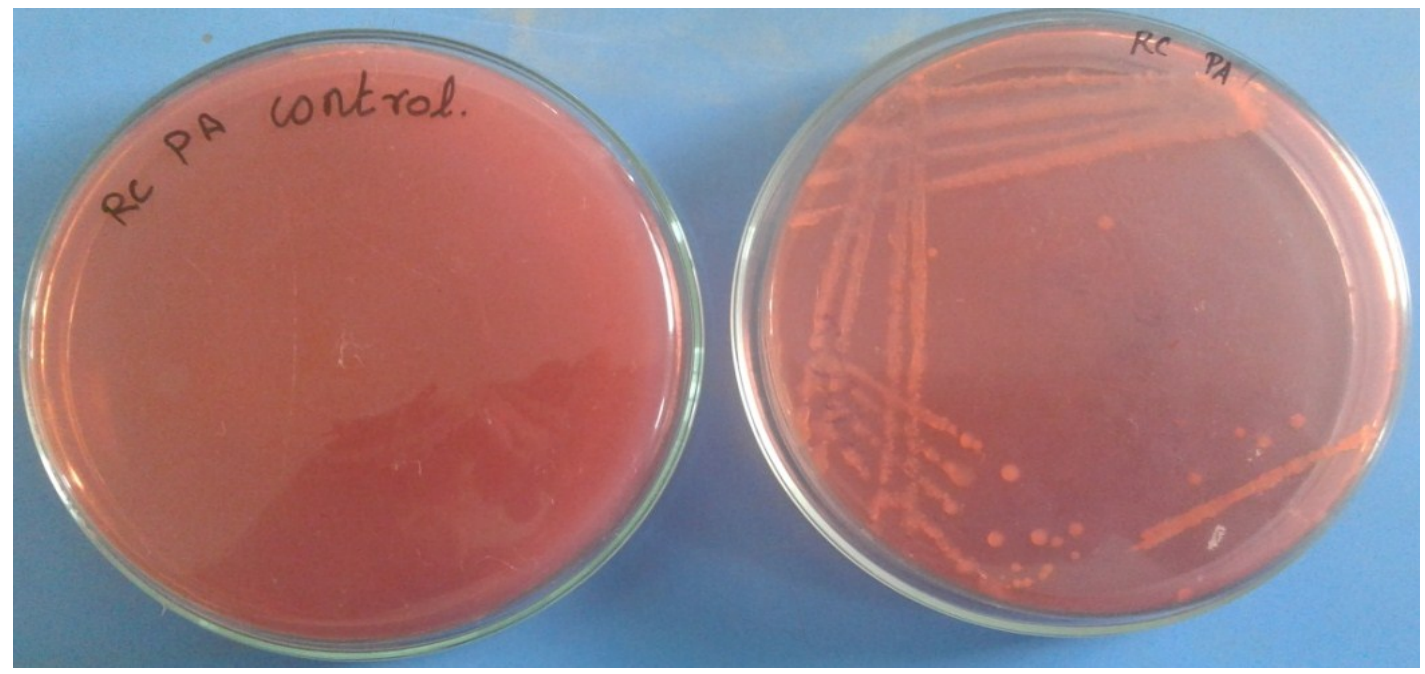

Fig. 2. Plate $A$ and $B$ shows the control and Azospirillum colonies on $R C$ agar medium respectively.

due to the pore size. The physicochemical properties of the soil of various paddy fields are given in Table 2.

The $\mathrm{pH}$ range was 7.4-7.9 in the study areas of paddy fields (Table 2). The bulk density of the paddy field soil samples was minimum of $1.130 \mathrm{~g}$ $\mathrm{cm} 3$ and maximum of $1.610 \mathrm{~g} \mathrm{~cm} 3$ recorded at Royappanpatti and Kottur respectively (Table 2). The water holding capacity (WHC) of the paddy field soil samples recorded maximum $(34.31 \%)$ at Kuchanoor and minimum of $18.25 \%$ at Royappanpatti (Table 2). The maximum (1.31) and minimum (1.11) electrical conductivity of paddy field soil samples was found in Uthamapalayam and Royappanpatti (Table 2). The organic carbon content of paddy soil samples had maximum value of $0.93 \%$ at Chinnamanur and minimum of $0.71 \%$ at Upparpatti (Table 2). Soil organic carbon helps prominently in structure of soil, water and nutrient availability (Lal et al., 1997).

Similar to our study reports, Vaneet kumar et al., (2016) studied the physico-chemical parameters of agricultural soil samples collected from banks of rivers Beas and Sutlej and reported the $\mathrm{pH}$ values from 7.37- 8.01, bulk density values to be 1.007 to $1.1846 \mathrm{~g} / \mathrm{cc}$ and water holding capacity of soils $29.0199 \%$. Studies on agricultural soil parameters at Punjab showed bulk density and water holding capacity values similar to our studies 0.75 to $0.84 \%$ and $50.54 \%$ to $57.12 \%$ respectively (Chahal et al., 2014).

Nutrients: The paddy field soil samples had total nitrogen content maximum and minimum of $1.72 \%$ and $0.78 \%$ observed at Chinnamanur and Royappanpatti (Table 3). The total nitrogen analyzed by Rashidi and Seilsepour, (2009) showed maximum and minimum content of $0.13 \%$ and $0.04 \%$ which was very low when compared to our study reports. An analysis of potato, carrots and corn cultivated soils showed values in the range of 0.39 to $0.75 \%$
(Calalang et al., 2014) which was similar to our results and the saline soils amended with farm manure showed value of 0.7 to $0.25 \%$, (Bharadwaj et al., 2011) which was quite low in to our study .

The paddy field soil samples possessed total phosphorus content to maximum $(0.177 \%)$ at Chinnamanur and minimum $(0.122 \%)$ at Upparpatti (Table 3 ). The paddy field soil samples had total potassium content maximum $(1.364 \%)$ at Kottur and minimum $1.273 \%$ at Erasakkanaickanur (Table 3).

Micronutrients: Plant micronutrients are required is very less, but their action depends on the mineral or organic complex which can be taken up by plant roots, soil $\mathrm{pH}$, redox potential and organic matter.

The available micronutrients like Zinc of the paddy field soil samples had highest and lowest values of 0.9 and $0.5 \%$ at Kuchanoor and Veerapandi respectively (Table 3 ). The Copper content of paddy field soil samples was found highest and lowest values of 2.3 and $1.7 \%$ at Kottur and Erasakkanaickanur respectively (Table 3). The iron content of the paddy field soil samples had highest and lowest values 10.9 and $8.2 \%$ respectively at Chinnamanur and Erasakkanaickanur (Table 3). The Manganese content of the paddy field soil samples possessed maximum and minimum values of 6.7 and $5.2 \%$ at paddy field soil samples Veerapandi and Kuchanur respectively (Table 3).

Available macronutrients: The available macronutrients as nitrogen for paddy field soil samples had highest and lowest values of 295 and $223 \mathrm{~kg} /$ ha at Chinnamanur and Erasakkanaickanur respectively (Table 3).

For available phosphorus in various paddy field soil samples had maximum (89 kg/ha) and minimum (49 kg/ha) values at Uthamapalayam and 
Kuchanoor (Table 3 ). Also for the available potassium in various paddy field soil samples had highest (790) and lowest (490) values at Chinnamanur and Upparpatti respectively (Table 3).

Similar micronutrient studies have been conducted in Northwest Frontier Province, Pakistan by Perveen et al. (1993) of agriculturally important soil series, agricultural soil samples collected from banks of rivers Beas and Sutlej, Punjab (Vaneet Kumar et al., 2016).

Similar results have been reported for the analysis of physic-chemical parameters of agricultural soil samples namely rhizosphere soil of Curcuma Ionga by Sumathi et al. (2008), secondary forests soil physico - chemical properties by Akbar et al., (2010), Senthil Kumar and Panneerselvam (2013) at Thiruvarur district, Tamilnadu, PrameenaSheeja (2015) at Periyakottai and Thirumangalkkattai, Kanimozhi and Panneerselvam (2017) at paddy field soils, Thanjavur, TN.

Isolation of Azospirillum: Azospirillum comes under proteobacteria ( $\alpha$ - subclass), having wide distribution and are present upto $10^{-7} / \mathrm{g}$ of rhizosphere soil of plants. They are diazotrophs for their ability to convert atmospheric nitrogen to ammonia available easily to plants under micro aerophilic conditions. They are known for their ability to plant growth promoting substances and increased water uptake for plants through root hair differentiation in plants.

Colony morphology: The Azospirillum sp form typical small white dense colonies on NFB malate agar when incubated for 7 days. Similarly, the isolates were also streaked on the plates containing RC (Roderquez Caceras) medium (figure 2), after incubation for seven days typical pink coloured scarlet colonies were formed.

Differentiation of Azospirillum from other root colonies: Among various paddy field soil samples, a total of eight isolates were selected and identified based on their colony formation in BMS medium (Table 4).

Population density of Azospirillum sp: In the different paddy field soil samples, the population of Azospirillumsp were recorded and presented in table 5. At Chinnamanur paddy field soil, highest population density of Azospirillumsp of $192 \times 10^{5}$ $\mathrm{CFU} / \mathrm{g}$ of soil was recorded. And the Royyanpatti, The lowest population density of Azospirillumsp of $91 \times 10^{5} \mathrm{CFU} / \mathrm{g}$ of soil has been obtained (Table 4).

Similar study results were reported by various researchers from various countries using rhizosphere region of soil in different crops. A total of 30 Azospirillum isolates were screened from 30 different paddy field soil samples collected from in and around Thanjavur district (Kanimozhi and Paneerselvam, 2011). The rhizospheres of vascular plants are always colonized with Azospirillumsp in a study by Cristyakova and Kalininskaya
(1984). The reports show that the population density of Azospirillumsp in the paddy field rhizosphere soil was $2 \times 10^{5}$ cells $/ g$ of soil, which was very low when compared to our study.

In eastern part of Libya, different strains of Azospirillum has been isolated from rhizospheric soils of 23 leguminous and non-leguminous plants. The results showed that highest density of Azospirillumsp are found in the rhizosphere of legumes (1.1 to $130.2 \times 10^{3} \mathrm{CFU} / \mathrm{g}$ soils), results similar to our Veerapandi study area (Attitallaet al., 2010). A total of 13 isolates of genus Azospirillumsp were isolated from rhizosphere of plants (Ki-Yoon et al., 2010).

\section{Conclusion}

The study brings about the physio-chemical parameters of eight paddy soil samples of Theni district. Of which, 3 paddy field soil samples were sandy clay loamy soil, the other 3 samples were loamy soils and 2 samples were sandy loam. It also revealed that the soil at Chinnamanur was found to be more of Azospirillum population due to high water holding capacity, $\mathrm{pH}$, organic carbon and other macro and micronutrients essential for supporting flora on soil. Thus, understanding the importance of soil fertility through biological process and bacterial population will improve the agricultural crop production and bring about sustainability.

\section{ACKNOWLEDGEMENTS}

The author Uma devi acknowledges the support and encouragement from the Head, Department of Microbiology and Biochemistry, Principal and management of Nadar Saraswathi College of Arts and Science, Theni. She also acknowledges the paddy farmers at various study areas of Theni district for support towards study.

\section{REFERENCES}

1. Ketterings, Q.M., Blair, J.M. and Marinissen, J.C.Y. (1997). Effects of earthworms on soil aggregate stability and carbon and nitrogen storage in a legume cover crop agroecosystem. Soil Biol. Biochem. 29, 401-408.

2. Paoletti, M. G. (1999). The role of earthworms for assessment of sustainability and as bioindicators. Agriculture. Ecosystems, Environment. 74, p. 37-155.

3. Narayan, R and Gupta, N.C., 2018. Isolation, cultural and physiological characterisation of Azospirillum from acidic soils of Ranchi. J Pharmacognosy and Phytochem. 7(4): 2611-2617.

4. Ivask, M., Kuu, A., Sizov, E. (2008). Abundance of earthworm species in Estonian arable soils. Eur. J. Soil Biol. 43: S39-S42.

5. Haiyambo. D.H., and Chimwamurombe, P.M., 2018. Isolation of the Azospirillum Species from the Rhizosphere of the Leguminous Bauhinia petersiana in North Eastern Namibia. Jordan J Bio Sci. 11, (4): $347-353$.

6. Lopez-de-Victoria, G., 1989. Chemotactic behaviour 
of deep subsurface bacteria toward carbohydrates, amino acids and a chlorinated alkene. M.Sc., Thesis University of Pureto Rica. Rio Piedras.

7. Mohamed, M.G., Mohamed H.M., Gameh M., ElRewainy H.M., 2018. Isolation and Characterization of Azospirillum Isolates from Soil and Their Effect on Growth and Yield of Wheat (Triticum aestivum L.) under Different Levels of Nitrogen Fertilizer. Assiut J. Agric. Sci. 49(3):107-116.

8. Jackson, M. L., 1973, Soil Chemical Analysis, Prentice Hall of India Private Limited, New Delhi.

9. Walkley, A.J. and Black, I.A. (1934) Estimation of soil organic carbon by the chromic acid titration method. Soil Sci. 37, 29-38.

10.Subbiah, B.V. and Asija, G.L. (1956). A rapid procedure for estimation of available nitrogen in soils. Curr. Sci., 25: 259-260.

11.Stanford, S. and English, L, 1949. Use of flame photometer in rapid soil tests for $\mathrm{K}$ and $\mathrm{Ca}$. Agron. ]., 41: 446-447.

12.Muthuvel, P. and Udayasoorian, C., 1999. Soil, plant, water are agrochemical analysis. Tamilnadu. Agricultural Unviersity, Coimbatore, India.Lindsay and Norvell, 1978.

13.Lindsay, W.L. and Norvell, W.A. (1978) Development of a Dtpa Soil Test for Zinc, Iron, Manganese, and Copper. Soil Science Society of America Journal, 42, 421-428.

14.Baldani, V. L. D. and Dobereiner, J., 1980, Hostplant specificity in the infection ofcereals with Azospirillum sp. Soil Biol. Bioche.,12:86-90.

15.Rodriguez Cacéres E. A. (1982) Improved medium for isolation of Azospirillum spp. Applied and Environmental Microbiology 44, 990-991.

16.Vaneet Kumar, Sandip Singh Bhatti and Avinash Kaur Nagpal, 2016. Seasonal analysis of physicochemical parameters of agricultural soil samples collected from banks of rivers Beas and Sutlej, Punjab, India. Journal of Chemical and Pharmaceutical Research, 8(8):439-449.

17.Chahal V., C Piar; A Nagpal; JK Katnoria; YB Pakade, Evaluation of heavy metals contamination and its genotoxicity in agricultural soil of Amritsar, Punjab, India. International Journal of Research in Chemistry and Environment, 2014, 4, 20-28.

18.Rashidi M; M Seilsepour. Modeling of soil total nitrogen based on soil organic carbon. Journal of Agricultural and Biological Science, 2009, 4, 1-5.

19.Calalang GD; L Bock; G Colinet. Establishing a soil reference system for fertility assessment and moni- toring at plot level in the high lands of Mindanao, Philippines. Eurasian Journal of Soil Science, 2014, 3, 189-196.

20.Bharadwaj A; V Khandelwal; P Choudhary; AK Bhatia. Comparative studies of organic enrichers in the improvement of physicochemical and microbiological characteristics of saline/usar soils. Journal of Chemical and Pharmaceutical Research, 2011, 3, 997-1003.

21.Perveen S, Tariq M, Farmanullah J, Khattak K, Hamid A (1993). Study of micronutrient status of some important sites of NWFP Pakistan., Sarhad J Agri, 9:467-473.

22.Sumathi CS, Balasubramanian V, Ramesh N, Rajesh Kannan V (2008). Influence of biotic and abiotic features on Curcuma longa L. plantation under tropical condition., Middle-East J Sci Res, 3:171-178.

23.Akbar $\mathrm{MH}$, Ahmed $\mathrm{OH}$, Jamaluddin AS, Nik Ab. Majid NM, Abdul-Hamid H, Jusop S, Hassan A, Yusof $\mathrm{KH}$, Abdu A (2010). Differences in soil physical and chemical properties of rehabilitated and secondary forests., American J Appl Sci, 7:1200-1209.

24.Senthil Kumar. R and Panneerselvam. A (2013). A Studies on Azospirillum isolated from the soils of Thiruvarur Dt., Tamilnadu, India. Adv. Appl. Sci. Res., $4(1): 86-93$.

25.PrameenaSheeja (2015). Assessment of macro and micronutrients in soils from Mannargudi Area, Thiruvarur, India. Res. J. Chem. Environ. Sci. 3, 6;32-37.

26.Kanimozhi, K and Panneerselvam, A., 2011. Investigation of soil characters and Azospirillum isolated from paddy soils of Thanjavurdistrict, East Coast of Tamilnadu, India. Archieves of Applied Science Research, 3 (2):525-536.

27.Cristyakova, I.K and Kalininskaya, TA., 1984. Azospirillum typically occur in the rhizosphere of vascular plants. Ser. Biol., 1: $149-153$.

28.Attitalla, I. H., Abobaker, M. A., Muftah, A. N., Amir, H. G., Latiffah, Z., Hasnah, M. J., Ibrahim, A. A. and Baharuddin, S., 2010, Occurrence and microbiological characteristics of Azospirillumstrains associated with leguminous and nonleguminous plants in $\mathrm{Al} \mathrm{jabal}$ Al Akhdar eco- Region, Libya. American- Eurasian J. Agric. Environ. Sci., 8(6): 617-625.

29.Ki-Yoon Kim, H. P. Deka Boruah, Chung-Woo Kim, C. C. Shagol and Tong-Min Sa, 2010, Isolation and evaluation of inoculation effect of Azospirillum sp. on growth, colonization and nutrient uptake of crops under green house condition. 19th World Congress of Soil Science, 1-6 August 2010, Brisbane, Australia. 